\title{
PENGARUH INTELLECTUAL CAPITAL PROGRAM STUDI TERHADAP KINERJA PROGRAM STUDI (STUDI PADA PROGRAM STUDI STRATA SATU DI BEKASI)
}

\author{
Ari Dewi Cahyati
}

\author{
Fakultas Ekonomi Universitas Islam 45 Bekasi \\ Jl. Cut Mutia Raya No. 83, Bekasi Timur, Kota Bekasi, Jawa Barat 17114 \\ Email: aridewi71@yahoo.co.id
}

Abstract

Objective of this study was to examine whether the indicators of intellectual capital (human capital affect to structure capital and relational capital) and whether the structure capital and relational capital structure affect to performance of under graduate program in Bekasi. Population in this study are chairman of under graduate program in Bekasi. Sample in this study using a convenience sampling. The research data include primary data and secondary data consisting of other written documents that are relevant to the research topic. This research data analysis techniques using the partial least square (PLS). Of the 71 questionnaires distributed that can be analyzed as much as 38 questionnaire so the response rate is $54,55 \%$. The statistical test indicate that human capital has positif significant affect on structure capital and relational capital, structure capital and relational capital has positive significant impact on the performance of undergraduate program in Bekasi.

Keywords: intellectual capital, performance of under graduate program

Abstrak

Tujuan penelitian ini adalah untuk menguji apakah indikator intellectual capital (human capital berpengaruh terhadap structure capital dan relational capital) 
dan apakan structure capital dan relational capital program studi berpengaruh terhadap kinerja prodi berpengaruh populasi dalam penelitian ini adalah ketua program studi di Kota Bekasi. Sampel dalam penelitian ini menggunakan convenience sampling. Data penelitian meliputi data primer yang diperoleh dengan cara menyebarkan data sekunder yang terdiri dari dokumen tertulis lainnya yang relevan dengan topik penelitian. Teknik analisis data penelitian ini menggunakan partial least square (PLS). Dari 71 kuesioner yang disebar yang dapat dianalisis sebanyak 38 kuesioner dengan demikian response rate dalam penelitian ini adalah $54,5 \%$. Hasil olah data statistic menemukan bahwa human capital berpengaruh positif signifikan terhadap structure capital, human capital berpengaruh postif signifikan terhadap relational capital, structure capital berpengaruh positif dan signifikan terhadap kinerja program studi dan relational capital berpengaruh positif signifikan terhadap kinerja program studi.

Kata kunci: intellectual capital, kinerja program studi

\section{PENDAHULUAN}

Perkembangan ekonomi baru dikendalikan oleh informasi dan pengetahuan, hal ini membawa sebuah peningkatan perhatian pada modal intelektual (Hong, 2007). Modal intelektual akhir-akhir ini memiliki peran kunci dalam upaya melakukan lompatan peningkatan nilai diberbagai perusahaan. Hal ini disebabkan adanya kesadaran bahwa modal intelektual merupakan landasan bagi perusahaan untuk unggul dan bertumbuh. Kesadaran ini antara lain ditandai dengan semakin seringnya istilah knowledge based company muncul dalam wacana bisnis. Istilah tersebut ditujukan terhadap perusahaan yang lebih mengandalkan pengelolaan modal intelektual sebagai sumber daya dan longterm growth-nya. Knowledge based company adalah perusahaan yang diisi oleh komunitas yang memiliki pengetahuan, keahlian, dan keterampilan. Ciri lainnya adalah perusahaan ini lebih mengandalkan pengetahuan dalam mempertajam daya saingnya, yaitu dengan lebih berinvestasi di bidang modal intelektual. Sebagai akibatnya, nilai dari knowledge based company utamanya ditentukan oleh modal intelektual yang dimiliki dan dikelolanya (Anugraheni, 2010).

Pengetahuan dan kapasitas inovasi secara efektif menjadi nilai penting bagi pengendalian aktivitas perusahaan sehingga perusahaan bisa menggunakan aset lainnya secara efisien dan ekonomis pada akhirnya perusahaan bisa mencapai keunggulan kompetitif(Ruppert dalam Sawarjuwono, Kadir, 2003). Akuntansi tidak mengakui intellectual capital sebagai aset, akuntansi hanya mengakui sebagian kecil dari intellctual capital sebagai aset misalnya paten yang dihasilkan oleh perusahaan. Ketidakmampuan perusahaan untuk mencatat intangible asset tersebut dalam neraca dikarenakan standar akuntansi yang ada saat ini belum mampu 
menangkap dan melaporkan investasi yang dikeluarkan untuk memperoleh sumber daya non fisik. Investasi sumber daya non fisik yang dapat ditangkap dan dilaporkan menurut standar akuntansi saat ini baru sebatas investasi dalam bentuk intellectual property.

Intellectual capital terdiri dari 3 (tiga) element, human capital, structure capital dan relational capital. Banyak pihak berpendapat bahwa aset perusahaan terpenting merupakan sumber daya manusia (human capital), karena human capital-lah yang mengendalikan aset lain yang dimiliki oleh perusahaan. Human capital yang melakukan pengelolaan atas aset perusahaan baik aset berwujud maupun aset tidak berwujud sehingga perusahaan bisa mendapatkan laba dan nilai tambah. Structure capital berhubungan kemampuan organisasi dalam memenuhi kebutuhan konsumen, standard structure capital adalah pengetahuan yang berada disekitar kegiatan rutin perusahaan, pengetahuan tersebut bisa kepemilikan hak intelektual, teknologi, penemuan, data, publikasi dan proses yang dapat dipatenkan, hak cipta atau rahasia dagang (Habiburrahman, 2008). Perusahaan yang ingin maju harus melakukan riset dan pengembangan dibandingkan dengan pesaingnya. Relational capital merupakan hasil dari kemampuan organisasi untuk berinteraksi secara positif dengan lingkungan termasuk supplier, pelanggan, competitor, pemegang saham, stake holder dan masyarakat). Pengelolaan dari ketiga elemen intellectual capital akan membantu perusahaan mencapai keunggulan kompetitif sehingga dapat membantu meningkatkan kinerja organisasi. Jika kinerja organisasi diukur dari kemampuan perusahaan dalam mendapatkan laba, maka intellectual capital merupakan sarana untuk penciptaan laba dan nilai tambah bagi perusahaan.

Perguruan tinggi merupakan organisasi dibawah departemen pendidikan nasional yang paling tidak mempunyai 2 (dua) peran penting dalam pembangunan yaitu: 1) sebagai agent of change (agen pembaharuan) 2) sebagai pencipta dan pendukung gagasan-gagasan baru (Cahyati, 2012). Oleh karena itu bisa dikatakan peran perguruan tinggi sangat besar terutama dalam pengembangan sumber daya manusia yang mampu mendorong, memelopori dan menciptakan gagasan-gagasan baru sehingga memberikan sumbangan kemajuan intelektual. Peran tersebut bisa terlaksana dengan melakukan tri dharma perguruan tinggi yaitu: 1) pendidikan dan pengajaran 2) penelitian 3) pengabdian masyarakat. Dalam hal ini program studi merupakan bagian dari universitas yang turut serta sebagai salah satu penentu keberhasilan universitas dalam melakasankan peran sebagai agent of change dan pencipta gagasan-gagasan baru.

Cahyati (2012) melakukan penelitian pengaruh indikator intellectual capital terhadap kinerja Program studi UNISMA Bekasi hasil penelitian menyatakan hanya dari indikator dari human capital yaitu learning and education dan kreativitas dan inovasi yang berpengaruh terhadap kinerja program studi. Seleim, et al (2004) meneliti Intelectual capital pada perusahaan software di Mesir, variabel intellectual capital yang diteliti adalah human capital, sturucture capital, relational capital. 
Hasil penelitian mengindikasikan bahwa indikator dari IC yang dilaporkan oleh CEO's memberikan arah untuk membangun knowledge yang dijadikan dasar untuk pengembangan IC di masa yang akan datang. Astuti dan Sabeni (2008) meneliti IC pada perusahaan di Jawa Tengah dengan menggunakan analisis SEM mengindikasikan bahwa human capital berhubungan secara positif dengan structure capital, human capital berpengaruh positif dengan customer capital, customer capital berpengaruh positif tetapi tidak signifikan terhadap kinerja perusahaan, structure capital berhubungan positif dan signifikan terhadap kinerja perusahaan.

Penelitian ini merupakan replikasi dari penelitian Cahyati (2012), Astuti dan Sabeni (2008). Perbedaan penelitian ini dengan penelitian Cahyati (2012) adalah penelitian pada penelitian sebelumnya hanya menguji pengaruh indikator intellectual capital terhadap kinerja prodi sedangkan penelitian ini selain menguji pengaruh indikator intellectual capital juga menguji pengaruh antar indikator Intellectual capital. Sedangkan beda penelitian ini dengan penelitian Astuti dan Sabeni (2008) adalah terletak pada sampel penelitian. Astuti dan Sabeni (2008) pada perusahaan di Jawa Tengah sedangkan penelitian ini mengambil sampel program studi strata satu yang ada di Kota Bekasi

Berdasarkan inkonsistensi hasil penelitian diatas peneliti tertarik untuk meneliti pengaruh indikator intellectual capital terhadap kinerja Program Studi Strata 1 pada perguruan tinggi di Kota Bekasi.

\section{TINJAUAN PUSTAKA}

\section{Pengertian Intelectual Capital}

Modal intelektual adalah suatu istilah yang memiliki berbagai definisi dalam teori-teori ekonomi yang berbeda. Satu-satunya definisi yang paling netral adalah suatu debat mengenai aktiva tak berwujud (intangibles) dalam ekonomi dan asumsi modal yang menciptakan kekayaan intelektual. Jenis modal ini jarang atau tak pernah muncul dalam praktik akuntansi.

Stewart (1997) dalam Subhan dan Citraningrum (2010) mendefinisikan IC sebagai materi intelektual yang telah diformalkan, dan dikembangkan untuk menciptakan kesejahteraan dengan memproduksi nilai lebih dari aset. Dalam kajian mengenai intellectual capital, banyak definisi yang telah diajukan oleh para peneliti diantaranya:

Mouritsen (1998) dalam cahyati (2012) mendefinisikan intellectual capital sebagai suatu proses pengelolaan teknologi yang mengkhususkan untuk menghitung prospek perusahaan di masa yang akan datang. Harrison dan Sullivan (1997) dalam Cahyati (2012) mendefinisikan IC mengemukakan bahwa kesuksesan perusahaan sangat dipengaruhi oleh usaha-usaha rutin perusahaan untuk memaksimalkan nilainilai organisasi yang berbeda-beda seperti peningkatan keuntungan, akuisisi inovasi 
dari perusahaan lain, loyalitas konsumen, pengurangan biaya dan perbaikan produktivitas.

Smedlund dan Poyhonen (2005) dalam Rupidara (2005) secara ringkas mewacanakan modal intelektual sebagai kapabilitas organisasi untuk menciptakan, melakukan transfer, dan mengimplementasikan pengetahuan.

\section{Komponen Intellectual Capital}

Peneliti terdahulu pada umumnya menyatakan bahwa intellectual capital terdiri dari tiga komponen utama (Sveiby, 1997 dan Bontis, 1998 ), yaitu : 1) Human capital 2) stucture capital 3) relational capital. Berikut ini merupakan definisi dari tiap elemen:

Komponen pertama adalah human capital, didefinisikan sebagai seperangkat nilai, perilaku, kualifikasi, dan keahlian yang dipunyai oleh karyawan yang dapat menghasilkan nilai bagi perusahaan (Ross, et al 1997, Mac Gregor et al 2004 dalam Loureiro, Teixeira, 2011). Human capital akan meningkat ketika perusahaan mampu menggunakan pengetahuan yang dimiliki oleh karyawannya (Sawarjuwono, 2003). Faktor lain dalam human capital ini adalah kreativitas yang menjadi inti dalam pengembangan perusahaan di masa depan. Mayo (2000) menyatakah bahwa yang mempengaruhi human capital adalah individual capability, individual motivasi, efektivitas kerja tim, iklim organisasi dan leadership. Sveivy (1997) mengemukakan bahwa kompetensi professional dapat diukur melalui pengalaman kerja, keahlian dan pelatihan, inovasi dan kreativitas.

Walaupun banyak peneliti yang menggolongkan human capital sebagai komponen dari intellectual capital, tidak seperti komponen intellectual capital lainnya, secara teknis dan hukum, human capital tidak dapat dimiliki perusahaan secara sepenuhnya (Edvinsson dan Malone, 1997; Stewart, 1998 dalam Choong, 2008).

Komponen kedua adalah stucture capital merupakan kemampuan organisasi atau perusahaan dalam memenuhi proses rutinitas perusahaan dan strukturnya yang mendukung usaha karyawan untuk menghasilkan kinerja intelektual yang optimal serta kinerja bisnis secara keseluruhan. Misalnya sistem operasional perusahaan, proses manufaktur, budaya organisasi, filosofi manajemen dan semua bentuk intellectual property yang dimiliki perusahaan (Sawarjuwono, 2003). Bontis (1998) menyatakan bahwa structure capital dapat dipengaruhi oleh sistem komunikasi, mekanisme atau sistem kerja. Sedangkan Sveiby (1997) menyatakan bahwa faktor yang mempengaruhi structure capital adalam sistem pengajaran, budaya organisasi dan kegiatan penelitian. Seperti Brooking dan Annie (1996) diadopsi oleh Partanen (1998) dalan Sawarjuwono (2003) menyatakan bahwa elemen structure capital terdiri dari 2 elemen yaitu intelectual property seperti merek, hak cipta seperti paten dan infrastructure capital seperti filosopi 
manajemen, budaya perusahaan, proses manajemen, metode perusahaan, financial relations, sistem informasi, net working systems.

Komponen ketiga adalah relational capital, merupakan hasil dari kemampuan organisasi untuk berinteraksi secara positif dengan lingkungan termasuk supplier, pelanggan, kompetitor, pemegang saham, stake holder dan masyarakat) untuk meningkatkan kesejahteraan dengan meningkatkan human capital dan structure capital (Marti, 2001 dalam Loureiro dan Teixeira, 2011). Menurut Allee (1998) dalam Kok (2005) relational capital dipengaruhi oleh relasi dengan konsumen, relasi dengan teman kerja. Sedangkan Sveiby (1997) menyatakan bahwa relational capital dapat digambarkan koneksi perusahaan dengan masyarakat atau publik.

\section{Pentingnya Mengukur Intelectual Capital pada Perguruan Tinggi}

Intellectual capital pada perguruan tinggi seharusnya diukur karena beberapa alasan: 1) Transparansi dari institusi publik seharusnya meningkat. Dalam masyarakat berbasis pengetahuan masyarakat menginginkan akses yang komprehensif mengenai informasi dimana dana publik dialokasikan. 2) Daftar peringkat universitas/perguruan tinggi perlu dibandingkan dengan benchmarking yang lain. Sehingga memberikan informasi universitas mana yang lebih baik. Universitas seharusnya menerapkan metode pembelajaran yang baru untuk diaplikasikan. Transfer good practice seharusnya ditingkatkan jika universitas dapat memperoleh akses intellectual capital-nya. 3) Kekuatan hubungan antara universitas/perguruan tinggi dan industri tidak mungkin dilakukan tanpa "common language". Kerjasama tersebut akan menyebabkan akademisi dan praktisi bisnis mampu mengembangkan hubungan yang saling menguntungkan. 4) Pengukuran IC dalam universitas/perguruan tinggi akan membuat peneliti lebih dekat dengan kebutuhan masyarakat dan industri. (Fazlagiz, 2005)

\section{Konsep dan Pengukuran Kinerja}

Kinerja organisasi atau kinerja perusahaan merupakan indikator tingkatan prestasi yang ingin dicapai dan mencerminkan keberhasilan perusahaan/manajer. Kinerja merupakan hasil yang dicapai dari anggota organisasi. Hal ini juga berarti bahwa kinerja organisasi dapat diukur dari sejauh mana organisasi mencapai tujuan yang telah ditetapkan sebelumnya.

Penilaian kinerja organisasi secara tradisional dapat ditinjau dari aspek keuangan yaitu dengan menilai rasio keuangan perusahaan. Brigham (1995;58) menyatakan bahwa ukuran keberhasilan organisasi dapat dilihat dari profitabilitasnya. Perusahaan mempunyai keunggulan bersaing apabila perusahaan tersebut mampu meraih laba yang tinggi dari rata-rata tingkat laba normal. Tingkat laba dapat dinyatakan dengan beberapa rasio yaitu rasio pengembalian aset (return on asset) dan rasio pengembalian modal (return on equity). 
Kaplan dan Norton (1992) mengembangkan pengukuran kinerja yang tidak hanya menekankan kinerja keuangan tetapi juga kinerja non keuangan yang disebut dengan balance score card. Konsep balance score card menekankan hubungan sebab akibat kinerja non keuangan dan kinerja keuangan. Pengukuran kinerja balance score card terdiri dari 4 (empat) perspektif yaitu : 1) kinerja keuangan 2) kepuasan pelanggan 3) perspektif bisnis internal 4) perspektif pertumbuhan dan pembalajaran.

\section{Model Penelitian}



\section{Gambar 1. Model Penelitian}

\section{Pengembangan Hipotesis}

Schultz (1993) dalam dalam Marimuthu et.al (2009) mendefinisikan human capital sebagai elemen kunci untuk meningkatkan aset perusahaan dan karyawan untuk dapat meningkatkan produktifitas dan mempertahankan keunggulan kompetitifnya. Mayo (2000) menyatakan bahwa human capital merupakan aset terpenting dalam perusahaan. Rastogi (2000) dalam Marimuthu, et al. (2009) menyatakan bahwa human capital merupakan input penting khususnya untuk organisasi khususnya untuk perbaikan karyawan secara berkesinambungan utamanya knowledge, keahlian, kompetensi yang membentuk individu yang memfasilitasi kreativitas personal, sosial dan ekonomi. Stucture capital merupakan kemampuan organisasi atau perusahaan dalam memenuhi proses rutinitas perusahaan dan strukturnya yang mendukung usaha karyawan untuk menghasilkan kinerja intelektual yang optimal serta kinerja bisnis secara keseluruhan. Sawarjuwono,(2003) Astuti dan Sabeni (2005) menyatakan sumber inovasi dan strategi pembaharuan perusahaan terletak pada tacit knowledge pegawai. Dengan kreativitas dan kecerdasannya, 
pegawai dapat mengubah praktek dan memikirkan solusi yang inovatif terhadap suatu masalah, sehingga akan dapat meningkatkan atau memperbaiki pengetahuan perusahaan (structural capital) misalnya rutinitas organisasi, prosedur-prosedur, sistem, budaya, database, dan sebagainya. Dengan demikian dapat disimpulkan bahwa human capital yang andal akan menghasilkan sistem perusahaan yang bagus serta intellectual property yang pada akhirnya akan mendorong perusahaan untuk meraih keunggulan kompetitif. Bontis (1998) dan Partiwi (2004), Astuti dan Sabeni (2005) menyatakan bahwa human capital berpengaruh positif terhadap structure capital. Bontis (1998) dan Partiwi (2004) yang menunjukkan bahwa terdapat hubungan positif dan signifikan antara human capital dan structural capital.

Dengan demikian dapat disimpulkan bahwa human capital yang andal akan menghasilkan sistem perusahaan yang bagus serta intellectual property yang pada akhirnya akan mendorong perusahaan untuk meraih keunggulan kompetitif.

\section{H1 : Human capital berpengaruh positif terhadap structure capital}

Astuti dan Sabeni (2005) menyatakan Human capital perusahaan memiliki potensi untuk membangun orientasi pasar bagi konsumen. Semakin baik kompetensi pegawai, maka akan semakin baik pegawai memahami kebutuhan konsumen dan akan semakin mampu pula mengembangakan customer capital untuk menahan loyalitas konsumen. Hal ini sesuai dengan Bontis (1998), Bontis et al (2000) dan Partiwi (2004) yang menemukan hubungan positif dan signifikan antara human capital dan customer capital.

$\mathrm{H} 2$ : Human capital berpengaruh positif terhadap relational capital

Structure capital merupakan kemampuan perusahaan atau organisasi dalam memenuhi proses rutinitas perusahaan yang mendukung usaha karyawan dalam mencapai kinerja intellectual optimal sehingga bisa menghasilkan keunggulan kompetitif serta kinerja bisnis secara keseluruhan. Astuti dan Sabeni (2005) menyatakan suatu organisasi mampu mengkodifikasikan pengetahuan perusahaan dan mengembangkan structural capital misalnya menciptakan rutinitas yang baik, maka keunggulan bersaing akan dapat dicapai yang secara relatif akan menghasilkan business performance yang lebih tinggi. Hal tersebut sesuai dengan Bontis (1998), Bontis et al (2000) dan Partiwi (2004) yang menemukan bahwa terdapat hubungan positif dan signifikan antara structural capital dengan business performance.

H3 : Structure capital positif berpengaruh terhadap kinerja program studi

Relational capital, merupakan hasil dari kemampuan organisasi untuk berinteraksi secara positif dengan lingkungan termasuk supplier, pelanggan, kompetitor, pemegang saham, stake holder dan masyarakat). Sisi positif dari hubungan yang 
baik dengan stakeholder adalah perusahaan bisa berinteraksi langsung dengan stakeholder sehingga perusahaan bisa memiliki kemampuan yang lebih baik untuk mempertahankan hubungan jangka panjang dengan stakeholder. Perguruan tinggi perlu mempunyai hubungan konsumen (mahasiswa, alumni, dan user), teman kerja (keanggotaan dan proyek kerja sama eksternal), publik (merupakan relasi dengan dunis industri) dan pendidikan lain dalam rangka untuk meningkatkan mutu pendidikan dan daya saing lulusan. Bontis (1998) menemukan hubungan positif dan signifikan relational capital terhadap kinerja perusahaan. Berdasarkan argument diatas penulis merumuskan hipotesis sebagai berikut:

H4 : Relational capital berpengaruh positif terhadap kinerja program studi

\section{METODE PENELITIAN}

\section{Jenis Penelitian}

Metode penelitian yang dipergunakan adalah metode penelitian survey, yaitu penelitian yang mengambil sampel dari populasi program studi strata satu pada perguruan tinggi di Bekasi. Alat pengumpulan data yang dipergunakan adalah dengan menggunakan kuesioner.

\section{Populasi dan Sampel}

Populasi dalam penelitian ini adalah ketua program studi strata satu yang ada di Bekasi. Sampel diambil menggunakan convenience sample yaitu memilih sampel dimana peneliti tidak mempunyai pertimbangan lain kecuali berdasarkan kemudahan saja.

Perhitungan sampel menurut Slovin (1960) sebagaimana dikutip dalam Suryati (2014), berdasarkan pernyataan tersebut maka jumlah sampel penelitian ini ditentukan populasi dengan tingkat signifikansi (toleransi tingkat kesalahan) $10 \%$ yaitu:

Rumus:

$\mathrm{n}=\frac{\mathrm{N}}{1+\mathrm{N} \mathrm{e}^{2}}$

Keterangan:

$\mathrm{n}=$ sampel yang diteliti

$\mathrm{N}=$ jumlah total sampel

$\mathrm{e}=$ standar eror

\section{Sumber dan Metode Pengumpulan Data}

\section{Jenis dan Sumber Data}

Dalam penelitian ini dipergunakan data kualitatif dan data kuantitatif yang bersumber dari data primer dan sekunder yang relevan dengan penelitian ini. 


\section{Teknik Pengumpulan Data}

Teknik pengumpulan data yang dipergunakan dalam penelitian ini adalah dengan menggunakan. Kuesioner untuk variable intellectual capital merupakan kuesioner yang dikembangkan Bontis (1997) yang disesuiakan dengan Intellectual Capital akademik (Cahyati, 2012), diisi sampai sejauh mana responden setuju dengan lima skala Likert ( 1 = sangat tidak setuju sampai dengan $4=$ sangat setuju). Sedangkan variable kinerja program studi menggunakan item-item dalam borang akreditasi dengan dipilih item yang penting atau memiliki point tinggi, diisi sampai sejauh mana responden setuju dengan empat skala Likert ( 1 = sangat tidak setuju sampai dengan $4=$ sangat setuju).

\section{Definisi Operasional Variabel}

\section{Variabel independen/eksogen}

Intelecctual Capital merupakan aset perusahaan yang tidak berwujud dan bisa digunakan dalam rangka untuk memperoleh kesuksesan organisasi. Intellectual capital terdiri atas: 1) human capital, didefinisikan sebagai seperangkat nilai, perilaku, kualifikasi, dan keahlian yang dipunyai oleh karyawan yang dapat menghasilkan nilai bagi perusahaan. Indikator dari human capital adalah learning and education, pengalaman dan keahlian, dan inovasi dan kreativitas. 2) Stucture capital merupakan kemampuan organisasi atau perusahaan dalam memenuhi proses rutinitas perusahaan dan strukturnya yang mendukung usaha karyawan untuk menghasilkan kinerja intelektual yang optimal serta kinerja bisnis secara keseluruhan. Indikator dari structure capital adalah: Sistem dan program, Penelitian dan pengembangan, dan paten. 3) relational capital, merupakan hasil dari kemampuan organisasi untuk berinteraksi secara positif dengan lingkungan termasuk supplier, pelanggan, competitor, pemegang saham, stake holder dan masyarakat. Indikator dari relational capital adalah strategi kemitraan, lisensi dan perjanjian kerja sama; hubungan mahasiswa, alumni dan pengguna lulusan; dan pengetahuan pelanggan.

\section{Variabel dependen/variable endogen}

Kinerja program studi hasil pencapain yang telah diperoleh program studi dalam hal ini diukur dengan menggunakan pengukuran yang dikembangkan oleh direktorat pendidikan tinggi (Dirjen DIKTI) yaitu peneliti menggunakan pertanyaan-pertanyaan dalam borang akreditasi Program Studi yang mempunyai bobot skor penilaian lebih dari 1,04 . 


\section{Pengolahan Data}

\section{Analisis Deskriptif}

Tujuan analisis deskriptif ini adalah untuk mengetahui gambaran intellectual capital program studi di perguruan tinggi strata satu di Bekasi.

\section{Analisis SEM}

Setelah melakukan analisis deskriptif maka tahap selanjutnya adalah menguji model intellectual capital.

Terdapat dua bagian analisis yang harus dilakukan dalam PLS, yaitu: Pertama, menilai outer model atau measurement model. Dalam penelitian ini menggunakan indicator refleksif sehingga yang menggunakan tiga kriteria untuk menilai outer model, yaitu convergent validity, composite reliability dan discriminant validity. Convergent validity dari model pengukuran dengan model reflektif indikator dinilai berdasarkan korelasi antara item score/component score dengan construct score yang dihitung dengan PLS. Ukuran reflektif dikatakan tinggi jika berkorelasi lebih dari 0,70 dengan konstruk yang ingin diukur. Namun demikian untuk penelitian tahap awal dari pengembangan skala pengukuran nilai loading 0,50 sampai 0,60 dianggap cukup (Chin, 1998 dalam Ghozali, 2006). Discriminant validity dari model pengukuran dengan reflektif indikator dinilai berdasarkan cross loading pengukuran dengan konstruk. Jika korelasi konstruk dengan item pengukuran lebih besar daripada ukuran konstruk lainnya, maka akan menunjukkan bahwa konstruk laten memprediksi ukuran pada blok yang lebih baik daripada ukuran blok lainnya. Metode lain untuk menilai discriminant validity adalah membandingkan nilai square root of average variance extracted (AVE) setiap konstruk dengan korelasi antara konstruk lainnya dalam model. Jika nilai akar $A V E$ setiap konstruk lebih besar daripada nilai korelasi antar konstruk dengan konstruk lainnya dalam model, maka dikatakan memiliki nilai discriminant validity yang baik. Pengukuran ini dapat digunakan untuk mengukur reabilitas component score variabel laten dan hasilnya lebih konservatif dibandingkan dengan composite reability. Direkomendasikan nilai $A V E$ harus lebih besar 0,50 (Fornnel dan Larcker, 1981 dalam Ghozali, 2006).

Kedua, Menilai inner model atau structural model. Model struktural dievaluasi dengan menggunakan $R$-square untuk konstruk dependen, stone-geisser q-square test untuk predictive relevance dan uji t serta signifikansi dari koefisien parameter jalur structural (Ghozali, 2006). Dalam menilai model dengan PLS dimulai dengan melihat $R$-square untuk setiap variabel laten dependen. Perubahan nilai $r$-square dapat digunakan untuk menilai pengaruh variabel laten independen tertentu terhadap variabel laten dependen apakah mempunyai pengaruh yang substantif. Di samping melihat nilai $r$-square, model PLS juga dievaluasi dengan melihat $Q$ Square predictive relevance untuk model konstruk. $Q$-Square predictive 
relevance mengukur seberapa baik nilai observasi dihasilkan oleh model dan juga estimasi parameternya. Nilai $Q$-Square predictive relevance lebih besar dari 0 menunjukkan bahwa model mempunyai nilai predictive relevance, sedangkan nilai $q$-Square predictive relevance kurang dari 0 menunjukkan bahwa model kurang memiliki predictive relevance (Ghozali, 2006).

\section{PEMBAHASAN}

\section{Gambaran Objek Penelitian}

Kota/Kabupaten Bekasi secara geografis terletak pada ketinggian 19 m diatas pemukaan laut. Kota/Kabupaten ini terlatrak diseblah timur dengan Jakarta. Berbatasan dengan Jakarta Timur dibagian barat, bagian selatan berbatasan dengan Bogor, sedangkan di sebalah timur berbatasan dengan kabupaten Karawang. Terdapat 86 program studi strata satu di Bekasi.

Dari 71 kuesioner yang dikirimkan, yang kembali dan layak untuk dianalisis sebanyak 38 kuesioner dengan tingkat respon rate sebesar 54,5\%. Responden yang berpartisipasi dalam penelitian ini berusia $>40$ tahun $40 \%$, beusia 31-40 tahun $37 \%$, dan beusia $<30$ tahun $18 \%$, dengan masa kerja kerja sebagai kaprodi $>5$ tahun (18\%), 2 sampai 3 tahun 36\% dan kurang dari 2 tahun 18\%, dan berpendidikan S2 33\%, S3 17\%.

\section{Statistik Deskriptif}

Tabel 1. Statistik Deskriptif

\begin{tabular}{|c|c|c|c|c|c|c|}
\hline & \multicolumn{5}{|c|}{ Descriptive Statistics } & \multirow[b]{2}{*}{ Std. Deviation } \\
\hline & $\mathrm{N}$ & & Minimum & Maximum & Mean & \\
\hline LE & & 38 & 2.33 & 3.67 & 3.0582 & .34423 \\
\hline PK & & 38 & 2.30 & 3.70 & 3.0842 & .34604 \\
\hline IK & & 38 & 2.30 & 3.60 & 3.0026 & .35678 \\
\hline SP & & 38 & 2.00 & 3.89 & 2.9097 & .41036 \\
\hline $\mathrm{RD}$ & & 38 & 2.00 & 3.70 & 2.8579 & .38809 \\
\hline $\mathrm{P}$ & & 38 & 1.00 & 3.60 & 2.2211 & .73270 \\
\hline SK & & 38 & 2.50 & 4.00 & 3.0947 & .35256 \\
\hline HUB & & 38 & 2.73 & 3.91 & 3.2058 & .31790 \\
\hline $\mathrm{PP}$ & & 38 & 2.10 & 3.50 & 3.0158 & .29549 \\
\hline Kinerja & & 38 & 1.82 & 3.00 & 2.4653 & .26596 \\
\hline
\end{tabular}

Dari beberapa indicator variable intellectual capital yang mempunyai nilai terkecil adalah paten yaitu sebesar 1 dengan standar deviasi 0.73270 sedangkan nilai terbesar adalah strategi kemitraan sebesar 4 dengan standar deviasi 0.35256. Sedangkan nilai mean terkecil juga paten yaitu sebesar 2.2211 dan nilai mean terbesar 
merupakan nilai hubungan dengan pelanggan sebesar 3.2058 dengan standar deviasi 0.31790 . variabel kinerja prodi mempunyai nilai minimum 1.82 , maksimum 3 dan mean 2,4652 dengan standard deviasi .26596. Hal ini mengindikasikan bahwa prodi strata satu di Bekasi masih kurang dalam dan merumuskan prosedur dan pengembangan paten. Selain itu nilai terbesar dan nilai mean terbesar merupakan strategi kemitraan dan hubungan pelanggan keduanya merupakan indicator dari relational capital, hal ini mengindikasikan bahwa program studi strata satu di Bekasi sudah melakukan upaya-upaya menjalin kerjasama dengan stake holder ataupun melakukan tracer study guna perbaikan prodi. Sedangkan variabel kinerja mempunya nilai mean 2,4652 hal ini mengindikasikan bahwa kinerja prodi menunjukkan angka diatas rata-rata (rata-rata kinerja adalah 2).

\section{Pengujian Hipotesis dan Pembahasan}

\section{Uji Outer Model}

\section{Pengujian model}

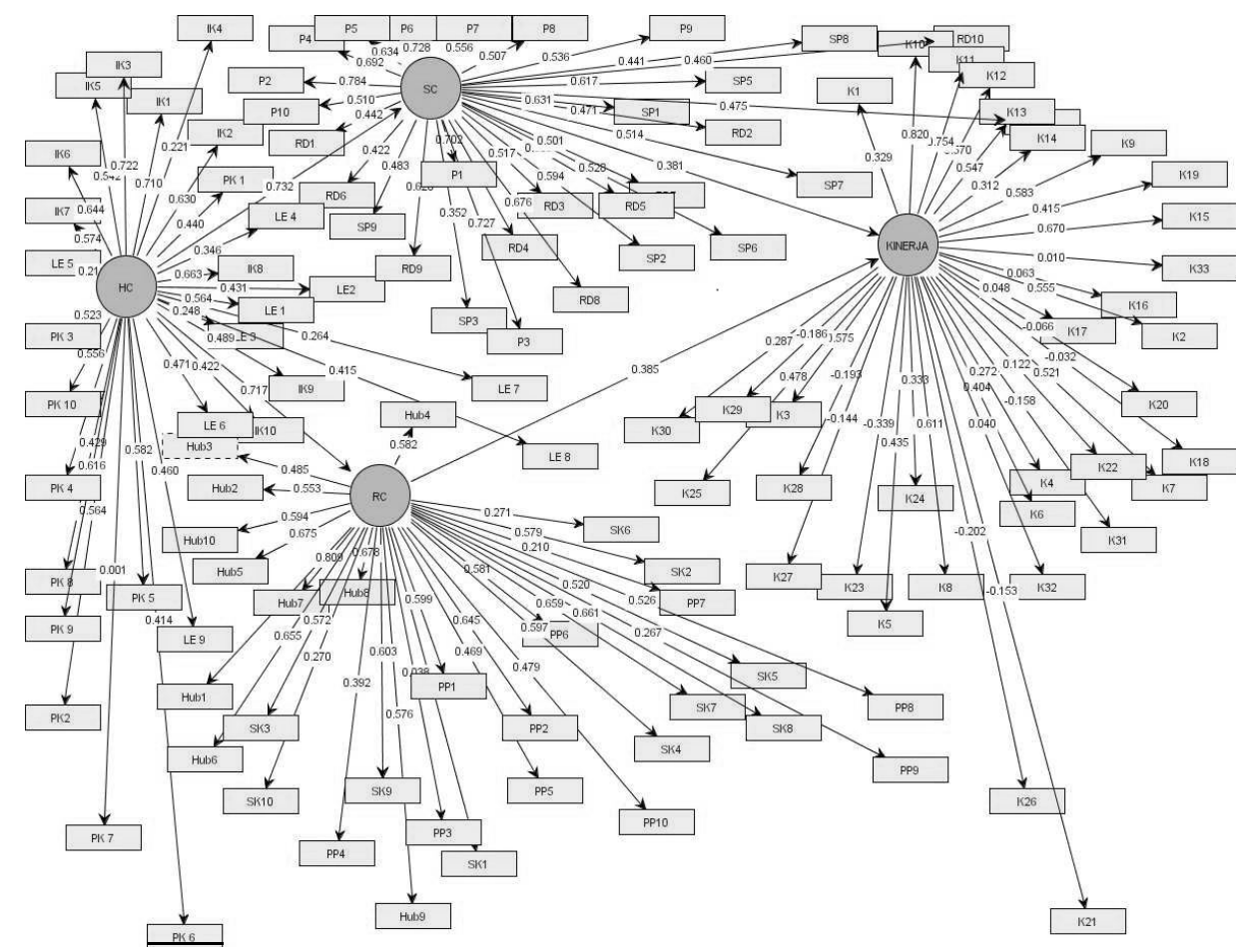

\section{Gambar 2. Pengujian Model}

Model pengukuran konstruk dengan indicator reflektif dapat dinilai dengan melihat convergent validity, discriminant validity dan composite reliability. 
Berdasarkan pengujian outer model 1 didapatkan bahwa faktor dari variabel (indicator) terdapat beberapa indikator yang mempunyai nilai loading dibawah 0,5 yaitu indicator LE 7, IK 4,LE 6,LE 5, LE 8, PK 10, PK 1, PK 4, PK 7, LE 9, SP 3, RD 2, SP 4, SP 8, RD 10, RD 1, SP 3, RD 6, SK 6, PP7, PP 9, PP 5, PP 10, PP 4, PP 3, HUB 3, K1,K14,K19,K 33, K16, K 17, K 20, K 18, K 21, K 22, K31, K 4,K 6 , K 32,K5, K 26, K 27, K 28, K 25, K 29, K 30. sehingga harus di drop dari pengujian. Pengujian kedua dilakukan dan kemudian masih ada beberapa indikator yang mempunyai loading dibawah 0,5 yaitu K 23, PP 8, SK 10, RD 7, RD 4, LE 4, PK 8, PK 6. sehingga harus di drop dari pengujian. Pengujian ketiga dilakukan dan kemudian masih ada beberapa indikator yang mempunyai loading dibawah 0,5 yaitu LE 3 dan IK 9. sehingga harus di drop dari pengujian. Dikarenakan beberapa indikator masih mempunyai loading dibawah 0,5 maka dikalukan pengujian model keempat. Pengujian keempat dilakukan dan ada satu indikator yaitu PK 9 mempunyai nilai outer model dibawah 0,5 sehingga di drop dari pengujian. Berikut model pengujian kelima dimana semua indikator mempunyai loading diatas 0,5 .

\section{Pengujian model 5}

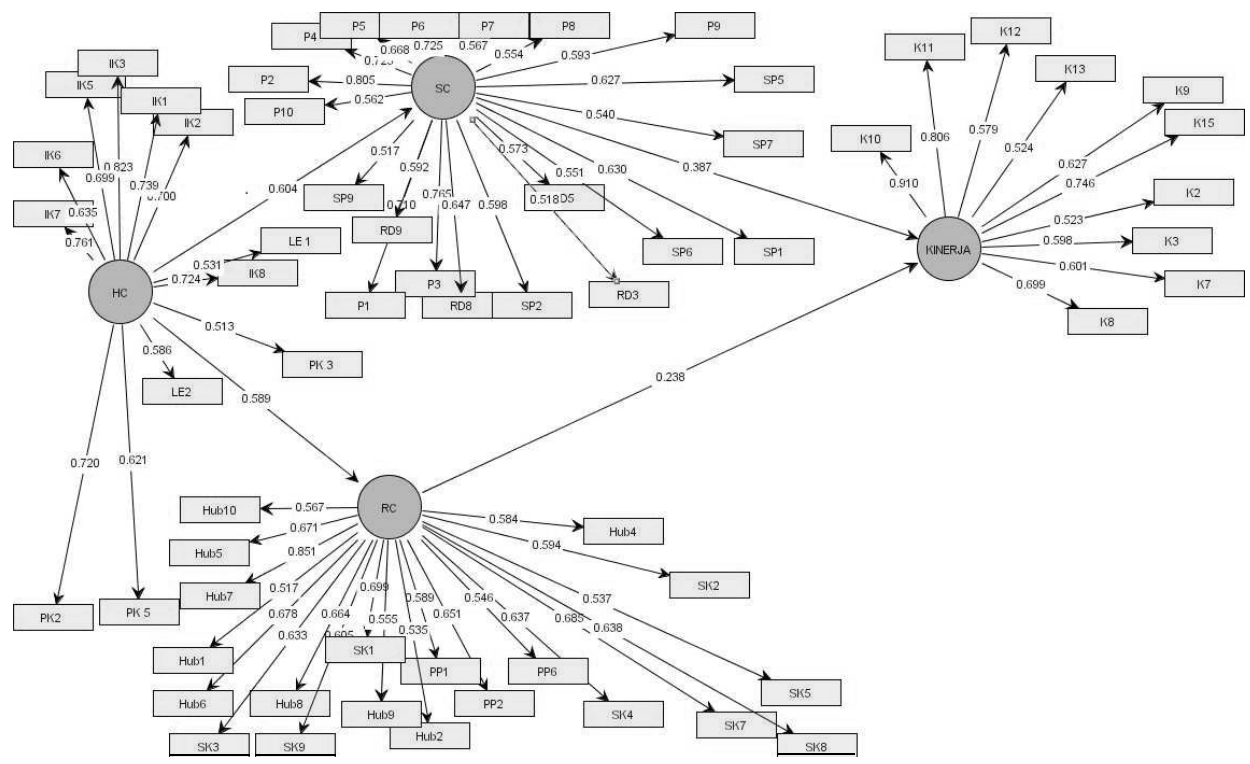

\section{Gambar 3. Pengujian Model 5}

Setelah lima kali pengujian Outer model didapatkan convergent validity semua konstruk mempunyai loading factor yang tinggi diatas 0,5 . Konstruk reflektif juga memiliki reliabilitas yang tinggi yang ditunjukkan dengan nilai composite realibitlity diatas 0,7 . Sedangkan composit diskriminan ditunjukkan dengan adanya 
matrik korelasi indikator dengan konstruknya yang lebih tinggi dibanding matrik korelasi indikator dengan konstruk lainnya (lihat lampiran) dan nilai AVE diatas 0,5 sesuai dengan yang direkomendasikan. Jadi secara keseluruhan konstruk mempunyai nilai reliabilitas yang baik.

Tabel 2. Nilai Reabilitas

\begin{tabular}{lll}
\hline Indicator & Composite Realibity & A VE \\
\hline Human Capital & 0,909 & 0.548 \\
Stucture Capital & 0.928 & 0.593 \\
Relational Capital & 0.927 & 0.692 \\
Kinerja program studi & 0.889 & 0.542 \\
\hline
\end{tabular}

\section{Uji Inner Model}

Pengujian inner model atau model structural dilakukan untuk melihat hubungan konstruk, nilai signifikansi dan R-squre dari model penelitian.

Tabel 3. Uji Inner Model

\begin{tabular}{|c|c|c|c|c|}
\hline Variabel & $\begin{array}{l}\text { Original } \\
\text { sample } \\
\text { Estimate }\end{array}$ & T.statistic & $\begin{array}{l}\text { Standard } \\
\text { deviation }\end{array}$ & Keterangan \\
\hline $\begin{array}{l}\text { Human Capital }(H C) \rightarrow \\
\text { Structure Capital }\end{array}$ & 0.604 & $7.729 *$ & 0.078 & T stat $>2,326$ \\
\hline $\begin{array}{l}\text { Human Capital }(H C) \rightarrow \\
\text { Relational Capital }\end{array}$ & 0.589 & $5.932 *$ & 0.099 & $\mathrm{~T}$ stat $>2,326$ \\
\hline $\begin{array}{ll}\text { Structure } & \text { Capital } \rightarrow \\
\text { Kinerja Prodi } & \end{array}$ & 0.387 & $2.301 * *$ & 0.168 & T stat $>1,645$ \\
\hline $\begin{array}{ll}\text { Relation al } & \text { Capital } \rightarrow \\
\text { Kinerja prodi } & \end{array}$ & 0.238 & $1.624 * * *$ & 0.147 & T stat $<1,282$ \\
\hline
\end{tabular}

* signifikan pada level 1\%, $* *$ signifikan pada level 5\%, $* * *$ signifikan pada level 10\%

\section{Hasil Penelitian}

\section{Hipotesis 1 Human capital berpengaruh terhadap structure capital}

Hasil pengujian menunjukkan human capital berpengaruh positif terhadap stucture capital pada level 1\% dengan arah hubungan positif dengan demikian hipotesis 1 diterima. Hal ini mengindikasikan bahwa human capital yang terdiri dari learning and education, Pengalaman dan keahlian dan inovasi dan kreativitas dosen yang ada di program studi studi strata satu di Bekasi berpengaruh terhadap structure capital yang terdiri dari sistem dan program, paten dan penelitian dan pengembangan. Semakin tinggi tingkat pendidikan dan pelatihan, inovasi dan kreativitas serta pengalaman dan keahlian dosen maka akan meningkatkan structure capital dalam hal ini sistem dan program, paten dan penelitian dan pengembangan akan semakin tinggi pula. Hal ini juga mengindikasikan bahwa semakin bagus human 
capital yang ada di prodi maka akan mendorong human capital untuk mengembangkan sturucture capital dalam hal ini sistem dan program yang ada di prodi, jumlah paten yang diperoleh, serta riset dan pengembangan. Sudah selayaknya bahwa prodi menstmulasi dan mendorong dosen untuk meningkatkan pendidikan dan pelatihan, inovasi dan kreativitas serta pengalaman dan keahlian dosen sehingga bisa mengembangkan structure capital dimana structure capital ini merupakan kemampuan organisasi atau perusahaan dalam memenuhi proses rutinitas perusahaan dan struktur capital akan mendukung usaha karyawan untuk menghasilkan kinerja intelektual yang optimal serta kinerja bisnis secara keseluruhan. Penelitian ini konsisten dengan Bontis (1998) dan Partiwi (2004), Astuti dan Sabeni (2005) menemukan hubungan positif signifikan human capital dan structural capital. Namun, pada penelitian Bontis et al (2000) hubungan human capital dan structural capital tergantung sektor industrinya. Hubungan antara human capital dan structural capital pada industri jasa bersifat positif tidak signifikan, sedangkan pada industri non jasa bersifat positif signifikan.

\section{Hipotesis 2 Human capital berpengaruh terhadap relational capital}

Hasil statistik menunjukkan bahwa human capital berpengaruh terhadap Relational Capital pada level 1\%. Dengan arah hubungan positif dengan demikian hipotesis 2 diterima. Hal ini mengindikasikan bahwa indikator-indikator human capital yang terdiri dari pelatihan dan pendidikan, inovasi dan kreativitas, pengalaman dan keahlian berpengaruh positif signifikan terhadap relational capital yang terdiri dari strategi kemitraan, pengalaman dan pengetahuan pelanggan dan hubungan dengan pelanggan. Hal ini juga mengindikasikan bahwa semakin bagus human capital yang ada di prodi maka program studi akan lebih memahami pengetahuan dengan pelanggan, lebih dekat hubungan dengan pelanggan dan lebih mengembangkan strategi kemitraan dengan pihak-pihak terkait. Program studi perlu untuk mengembangkan relational capital dalam hal ini melakukan tracer study dengan mengakomodir masukan dari pengguna, alumni dan mahasiswa guna merumuskan kurikulum, merumuskan strategi pengembangan pasar dan melakukan continuous improvement bagi program studi. Astuti, sabeni (2005) menyatakan bahwa human capital di dalam suatu organisasi merupakan sumber inovasi dan pembaharuan bagi perusahaan memilikki potensi penuh untuk membangun orientasi pasar bagi konsumennya. Penelitian ini konsisten dengan Bontis (1998), (Bontis, et al., 2000) dan Partiwi (2004) menemukan hubungan positif signifikan antara human capital dan customer capital.

\section{Hipotesis 3 Structure capital berpengaruh terhadap kinerja prodi}

Hasil statistik didapatkan hasil bahwa structure capital yang terdiri dari sistem dan program, paten dan penelitian dan pengembangan berpengaruh pada level 5\% 
terhadap kinerja prodi dengan arah hubungan positif dengan demikian hipotesis 3 diterima. Hal ini sesuai teori yang menyatakan bahwa sistem dan program, paten dan penelitian dan pengembangan yang bagus maka akan akan meningkatkan kinerja. Hal ini juga mengindikasikan bahwa semakin bagus sistem dan program yang ada di prodi, semakin banyak jumlah paten yang dihasilkan program studi dan semakin banyak jumlah riset dan pengembangan yang dihasilkan program studi maka kinerja program studi juga semakin bagus. Peneltian ini konsisten dengan Bontis (1998) dan Partiwi (2004), Astuti dan Sabeni (2005) menemukan hubungan positif signifikan structural capital dan kinerja dan tidak konsisten dengan Cahyati (2012) yang menyatakan sistem dan program, paten dan penelitian dan pengembangan tidak berpengaruh terhadap kinerja prodi

\section{Hipotesis 4 Pengaruh relational capital terhadap kinerja prodi}

Hasil uji statistic menunjukkan bahwa relational capital berpengaruh signifikan dengan kinerja prodi pada level 10\% dengan arah hubungan posistif. Hal ini mengindikasikan semakin tinggi hubungan dengan pelanggan, pengetahuan pelanggan dan strategi kemitraan maka kinerja prodi akan meningkat. Pengelolaan customer capital yang baik akan menyebabkan kompetensi dalam aktivitas organisasi atau respon terhadap perubahan pasar dapat dikembangkan. Hal ini mengindikasikan bahwa relational capital yang dilakukan program studi seperti tracer study, hubungan dengan stake holder dan kerjasama program studi dengan stake holder terbukti meningkatkan kinerja prodi. Hasil Penelitian ini tidak konsisten dengan Bontis (2000) dimana Bontis menemukan pengaruh positif namun tidak signifikan antara customer capital (relational capital) terhadap kinerja perusahaan dan Cahyati (2012) yang menemukan tidak terdapat pegaruh strategi kemitraan, hubungan pelanngan dan pengetahuan pelanggan terhadap kinerja prodi.

\section{SIMPULAN}

Berdasarkan hasil penelitian yang telah dilakukan, maka dapat disimpulkan sebagai berikut: human capital berpengaruh positif terhadap structure capital. human capital berpengaruh positif terhadap relational capital. structure capital berpengaruh positif terhadap kinerja program studi strata satu di Bekasi. relational capital berpengaruh posistif terhadap kinerja program studi strata satu di Bekasi.

Penelitian ini memilki keterbatasan dalam melakukan penelitian antara lain: 1) Penelitian ini tidak menguji pengaruh stucture capital terhadap relational capital, 2) penelitian ini terbatas hanya menguji intellectual capital dan kinerja prodi strata satu di Bekasi, 3) penelitian ini jumlah sampel hanya 38, penggunaan sampel yang lebih banyak diharapkan akan memberikan hasil yang lebih valid, 4) penelitian ini menggunakan pengukuran data primer untuk mengukur IC dan kinerja prodi. 
Melihat kesimpulan yang telah diuraikan, maka dapat disaran bagi penelitian selanjutnya antara lain: 1) penelitian selanjutnya bisa diupayakan jumlah sampel yang lebih besar sehingga mungkin bisa diperoleh hasil yang lebih valid, 2) penelitian selanjutnya bisa menguji interaksi antara structure capital dengan relational capital, 3) penelitian selanjutnya bisa menggunakan pengukuran intellectual capital dan kinerja yang lain. 4) penelitian selanjutnya bisa menggunakan alat analisis SEM yang lain misalkan AMOS dan LISREL.

\section{DAFTAR PUSTAKA}

Anugraheni. 2010. Analisis Pengaruh Modal Intelektual Terhadap Kinerja Perusahaan. Skripsi. Universitas Diponegoro. Semarang.

Astuti dan Sabeni. 2008. Hubungan Intellectual Capital and Business performance dengan Diamond Specification: Sebuah perspektifAkuntansi. SNA VIII Solo, 15-16 September 2005 .

Berg, Herman, A., Van. 2007. Model of intellectual capital Measurement. www.IGIglobal.com diakses pada 10 januari 2012.

Bontis. 1998. Intellectual capital: An exploratory Study that develop Measures and Models. Management Decisions

Bontis, Keow, dan Richardson. 2000. Intellectual capital and business performance in the Pharmaceutical Sector of Jordan. http. Emeraldinsight.com/0025-1747.thm diakses pada tanggal 5 januari 2012

Bontis. 2000. Knoledge assets: a review model of used to measure intellectual capital. IJMR vol.3 p.41-60

Brigham. 1995. Fundamental of Financial management. Eight Edition. Dryden Press. Harcout Brace College Publishers: New York.

Cahyati, Ari Dewi. 2012. Pengaruh Intellectual Capital Program Studi terhadap Kinerja Program Studi (Studi pada Program Studi UNISMA Bekasi). Jurnal Riset Akuntansi dan Komputerisasi Akuntansi Vol.4 No. 2 Agustus 2012.

Fazlagiz, A.2005. Measuring The Intellectual capital in University. http.www.oecd.org. diakses pada 5 Januari 2012.

Ferdinand, A. 2002. Structural Equation Modelling dalam Penelitian Manajemen. Semarang: Universitas Diponegoro.

Firer, S. dan S.M. Williams. 2003. Intellectual capital and traditional measures of corporate performance. Journal of Intellectual capital. Vol. 4. No. 3. pp. 348-360.

Ghozali, I. 2006. Structural Equation Modelling Metode Alternatif dengan Partial Least Square. Semarang: Badan Penerbit Undip.

Habiburrachman. 2008. Kajian tentang Pentingnya Intellectual capital dalam mendukung Peningkatan Kinerja Perusahaan. Jurnal Administrasi dan Bisnis, Vol 2. No.1 Juli 2008.

Hong, Pew Tan, David Plowman, dan Hancock. 2007. Intellectual Capital and Financial Returns of Companies. Journal of Intellectual Capital . Vol 8. No. 2. pp. 76-95.

Kooisdtra dan Zijstra. 2001. Reporting on Intellectual Capital. Accounting, Auditing and accountability Journal Vol 14 p.456-476.

El-Muhasaba, Vol. 7, No 1, Januari 2016 
Kaplan dan Norton. 1996. The Balanced Scorecard: Translating Strategy Into Action, Harvard Business Scholl press: Boston.

Kok, J.A. 2005. The Internationalization of Universities Through of Management of Their Intellectual capital. Http.www.fm.upr.si/zalozba. Diakes pada tanggal 5 Januari 2012.

Kurniawan, Khaerudin. tanpa tahun. Membangun Kultur Akademik di Perguruan tinggi. Http.UPI.com. diakse pada 12 Januari 2012.

Kuryanto, B. 2008. Pengaruh Modal Intelektual terhadap Kinerja Perusahaan. Proceeding SNA XI. Pontianak.

Loureiro, Miguel Gonzalez, Antonio Moreira Teixeira. 2011. Intellectual in Public Universities: the performance-Oriented approach. Http.SSRN.Com. diakses pada tanggal 5 Januari 2012.

Marimuthu, Maran. Lawrence Arokiasamy, Maimul Ismail. 2009. Human Capital Development and its impact on firm performance: Evidence from Developmental Economics. The Journal of International Social Research Volume 2 / 8 Summer 2009.

Mayo, A. 2000. The Role of Employee Development in The Growth of Intellectual capital: Personal Review, Vol.2 No.29. http:www.emerald-library.com diakses pada tanggal 5 Januari 2012.

Ongkorahardjo, S., Rachmawati. 2008. Analisis Pengaruh Human Capital terhadap Kinerja Perusahaan (Studi Empiris pada Kantor Akuntan Publik di Indonesia. Jurnal Akuntansi dan Keuangan Vol.10 No.1 Mei 2008: 11-21.

Rafiee, M., Mohammad, M., Raoul, A. 2010. Formulating and elaborating a Model for Recognition of Intelelctual Capital in Irania Universities. World Apllied Science Journal 10. ISSN 1818-4952.

Rupidara, N. 2008. Modal Intelektual dan Strategi Pengembangan Organisasi dan Sumber Daya Manusia. Paper disajikan pada Diskusi Modal Intelektual UKSW. Salatiga, 21 February 2008.

Sangkala. 2006. Intelectual Capital Management. Jakarta: Yapensi.

Seleim, A., Bontis. 2004. Intelelctual Capital in Egyptian Software firm. WWW. Emeraldinsight.com diakses pada 12 Februari 2014.

Singarimbun, M., dan Sofian, E. 1995. Metode Penelitian Survey. Yogyakarta: LPEES.

Sawarjuwono, T., Aguatine, P.K. 2003. Intellectual capital: Perlakuan, Pengukuran dan Pelaporan ( Sebuah Library Research) Jurnal Akuntansi dan Keuangan, Vol 3, No, 1.

Solimun. 2002. Structural Equation Modelling Lisrel dan AMOS, Universitas Negeri Malang.

Subkhan, D.P.C. 2010. Pengaruh Intellectual capital terhadap Kinerja Keuangan pada Perbankan di BEI periode 2005-2007. Jurnal Dinamika Akuntansi Vol.2 No.1 Maret 2010.

Subiyanto, I. 2000. Metodologi Penelitian, Manajemen dan Akuntansi. Yogyakarta: UPPAMPYKPN.

Suryati, A. 2014. Pengaruh Pengetahuan Akuntansi, Kepribadian Wirausaha dan Kemitraan Usaha terhadap Kinerja Manajerial Pada Usaha Kecil Menengah (UKM) di Kota Bekasi.

Sveiby. 1997. The New Organization Wealth: Managing and Measuring Knowledge based Assets. San Francisco: Barret 2005 Kohler Publisher.

El-Muhasaba, Vol. 7, No 1, Januari 2016 
Tseng dan Goo. 2005. Intellectual Capital and Corporate Value in an emerging economy: Empirical study of Taiwanese Manufacturers. $R \& D$ Management Journal Vol.35 No.2.p.187-201.

Umar, H. 2003. Metode Riset Perilaku Organisasi, Cetakan Pertama. Jakarta: PT Gramedia Pustaka Utama.

Wang dan Chang. 2005. Intellectual Capital and Performance in causal Models. Journal of Intelelctual Capital Vol5, p171-180. 